\title{
Participation of Alcoholic Beverages in Carcinogenesis of the Esophagus, Liver and Pancreas
}

\author{
Akio HoRIE \\ Department of Pathology, School of Medicine, University of Occupational and Environmental Health, \\ Kitakyushu 807, Japan
}

Abstract: This paper is an introductory review of our previous reports concerning the relationship between ingestion of alcoholic beverages and cancer of the esophagus, liver, and pancreas. As for esophageal carcinoma, drinking of aqueous ethanol solution may accelerate esophageal carcinogenesis by promoting penetration of carcinogenic aromatic hydrocarbons into the mucosa as a solvent.

Though pure ethanolic solution itself failed to demonstrate carcinogenic activity, undistilled sake and its distillation residues had a promoting potency which approximated the established one of croton oil.

On the other hand, among 29 autopsied alcoholics, there was neither carcinoma of the liver nor of the pancreas, though some of them had the lesions of hepatic cirrhosis and chronic pancreatitis, in addition to occurrence of an esophageal carcinoma.

Key words: alcohol, carcinogenesis, esophageal cancer, liver cirrhosis, pancreatitis.

(Received 10 January 1979)

With regard to the cancer incidence of the digestive organs, many epidemiological investigations have reported that esophageal carcinoma has a high correlation with consumption of tobacco and alcoholic beverages (Kuratsune et al., 1965). Moreover, numerous clinicopathological studies have suggested that drinking of alcoholic beverages accelerated hepatic cirrhosis (Sereny \& Devenyi, 1972; Okudaira, 1966) and chronic pancreatitis frequently associated with lithiasis (Moriwaki et al., 1973; Sarles, 1974).

Both prospective and retrospective studies published in recent years have denoted a high correlation between smoking and lung cancer (Doll \& Hill, 1964). However, it has not been so well established that drinking of alcoholic beverages implies an enhanced risk of malignant neoplasms in the digestive organs. This paper intends to clarify the possible role of alcohol consumption in the initiation of esophageal cancer and to critically estimate the carcinogenesis of the liver and pancreas, based mainly on a review of our previous reports.

Some mutagenic aromatic hydrocarbons, which are among the environmental carcinogens, may not be effective unless they penetrate the basal layer of the mucosa, where the epithelial cells exhibit mitotic activity. From this point of view, Kuratsune et al. (1965) conducted a comparative study of the penetration of benzo[a]pyrene (BP) and other aromatic hydrocarbons in the esophageal mucosa of mice using different solvents. The results indicated that $\mathrm{BP}$ and other aromatic hydrocarbons in ethanol or aqueous ethanol solution quickly entered the esophageal mucosa, while the same hydrocarbons 
dissolved in olive oil hardly penetrated the epithelium (Fig. 1). These experimental results were amplified by the fact that BP and other aromatic hydrocarbons were exceedingly soluble in proportion to the concentration of ethanol in the aqueous solution.

An epidemiological study (Segi \& Kurihara, 1969) has indicated a contrast in esophageal carcinoma between men and women in France. This difference has been interpreted to be a result of the higher frequency of wine consumption by men in that country than by women.

Horie et al. (1965), in a study designed by Kuratsune, tried to experimentally produce esophageal cancer using an ethanolic solution of BP. In addition to many papillomas of the esophagus and forestomach, one carcinoma of the esophagus and two of the forestomach were produced in mice (initial number: 63) which had been orally administered an ethanolic solution of BP (Fig. 2). The report also described that no cancer was detected among mice administered only diluted ethanol. The mice were administered orally a $0.003 \%$ solution of $\mathrm{BP}$ in $70 \%$ ethanol from a drinking cylinder 5 days a week. At noon on Saturday and on Wednesday evening, the cylinders were replaced with water bottles, allowing the animals free access to water until Monday and Thursday morning respectively.

Esophageal infusion was also carried out by injecting $0.04 \mathrm{ml}$ of $0.043 \% \mathrm{BP}$ solution in $95 \%$ ethanol through a Vinylon tube into the mice once a week for 23 weeks. Besides thirteen papillomas of the esophagus, 13 carcinomas and 24 papillomas of the forestomach were produced. From a histopathological standpoint, the forestomach lined by a squamous epithelium was considered to be an amplified portion of the terminal esophagus which accumulates ingested materials. Therefore, the forestomach should be regarded as part of the esophageal mucosa and not the gastric mucosa proper. Consequently, squamous cell carcinoma of the forestomach may fall under the category of esophageal carcinoma. The above-mentioned findings demonstrated that drinking an ethanolic solution may accelerate esophageal carcinogenesis by promoting penetration of carcinogenic hydrocarbons in the mucosa as a solvent.

However, administration of whisky and sake failed to cause esophageal carcinoma in mice. Kuratsune et al. (1971), tested whether or not the residues of whisky and sake had any cocarcinogenic effect. Using 7,12-dimethylbenz $[a]$ anthracene as an initiator, undistilled sake and its distillation residues had a promoting potency which was almost the same as the established promoting potency of croton oil. However, whisky hardly seemed to have any tumor promoting activity which approximated that of croton oil.

Many reports (Sagebiel et al., 1963; Creutzfeldt \& Schmidt, 1970) have suggested that excessive and prolonged alcohol consumption by man has some toxic effects on the liver and pancreas. Twenty-nine cases of alcoholics were selected and hepatic lesions in them were reviewed by Horie et al. (1978), among 500 autopsies conducted from July, 1966, to August, 1972, at Kurate Kyoritsu Hospital, located in a former coal field in Fukuoka Prefecture, Japan. All cases autopsied as alcoholics were males who had consumed more than $360 \mathrm{ml}$ of alcoholic beverages daily for at least 7 years. The age distribution of alcoholics peaks at 50 years (average 53 year-old), which was 15 years shorter than the 

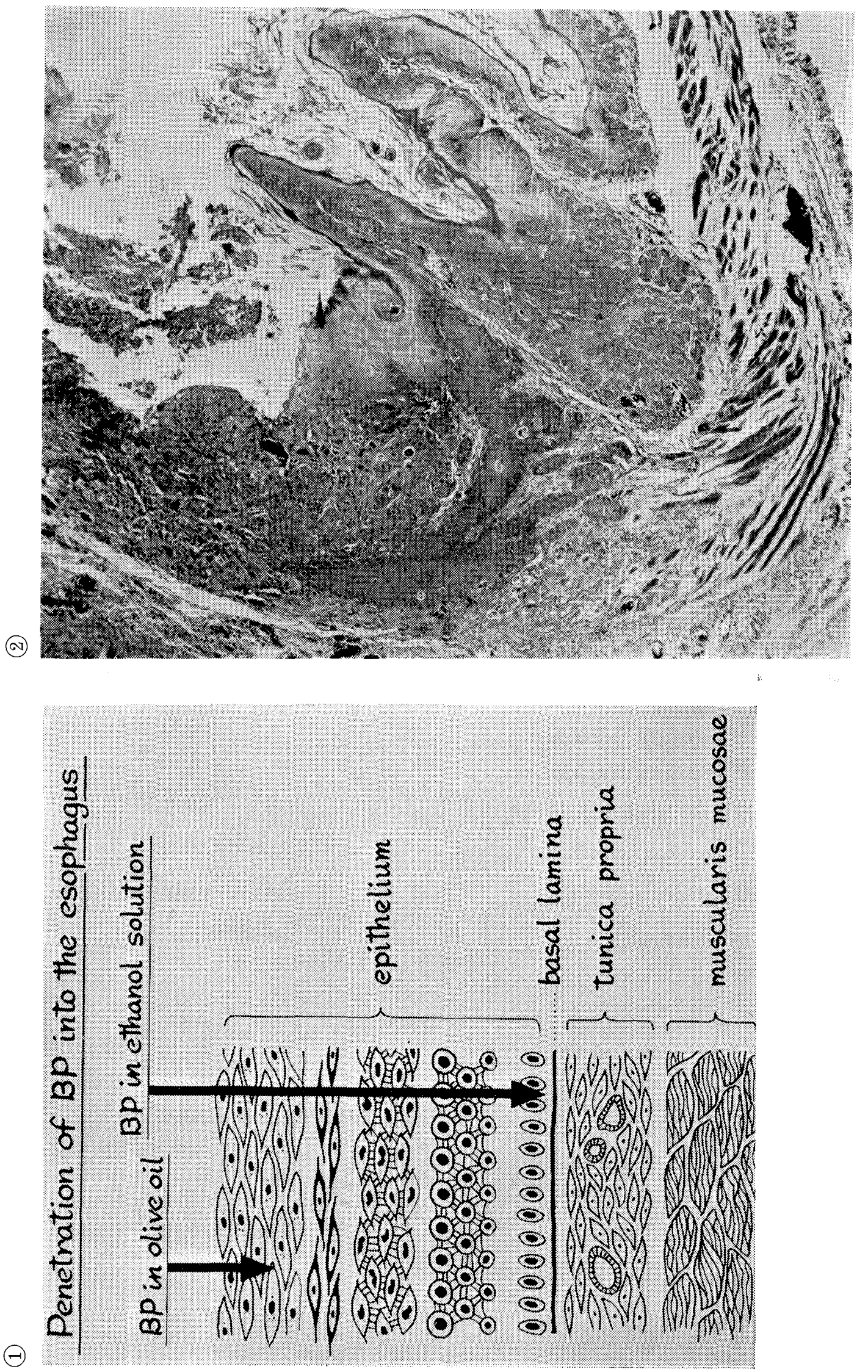

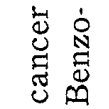
陆㟧

$\therefore \dot{0}$

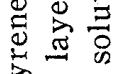

总薄:

突

ए

㟧岳

당ㅇㅇ

:

总

in

$\exists$

$\Rightarrow$ of

उ

को

密总

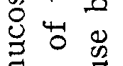

घ

范

要

范

券焉至

岁

घ 3 훙

푣ㄹ

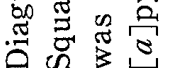

-

家 

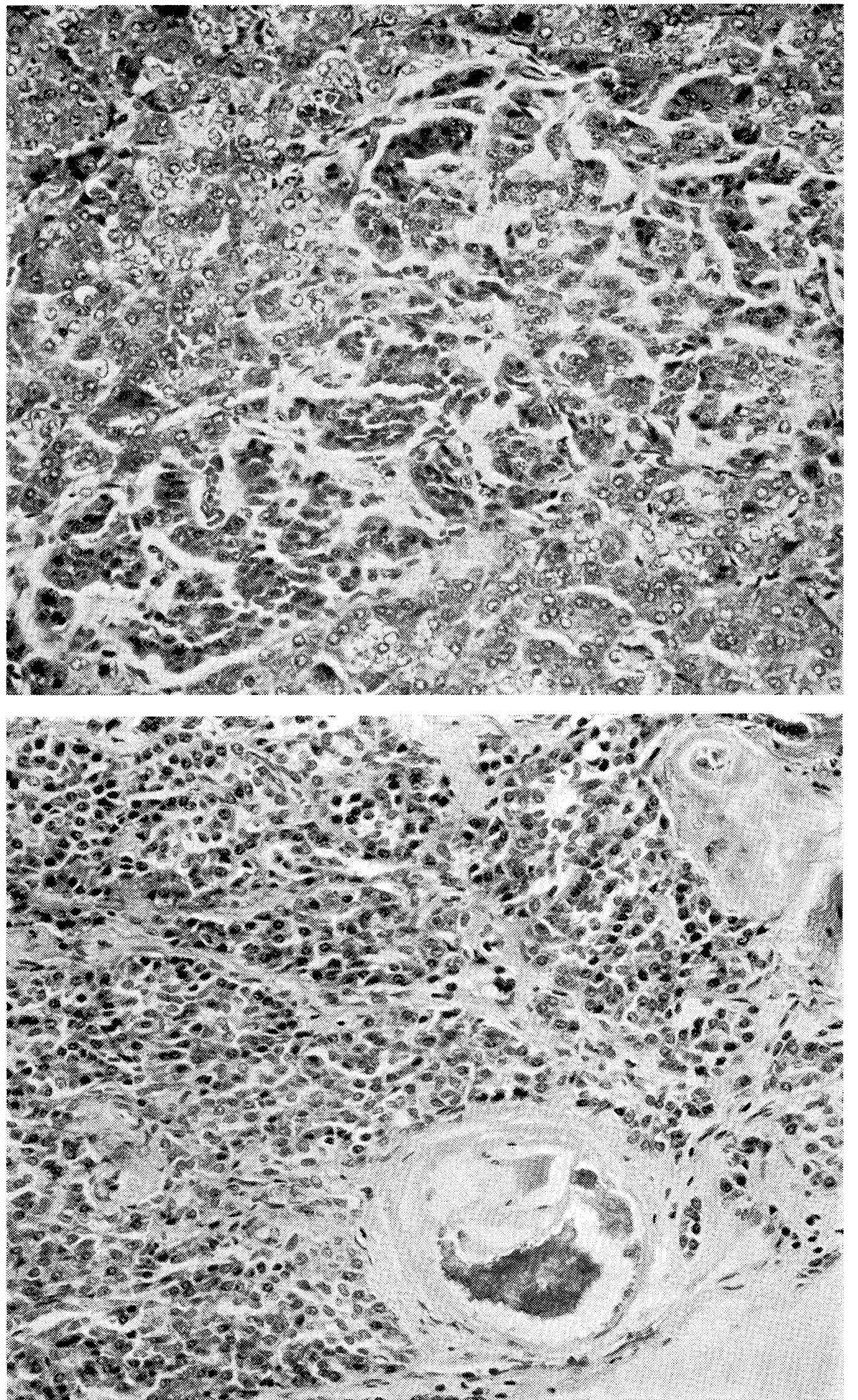

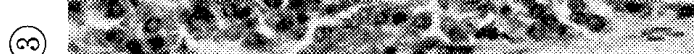


average years for the control cases.

Cases of liver cirrhosis were $9(31 \%)$ out of 29 and were of the following types: Laennec, 5; postnecrotic, 2; fatty, 1; and commencing, 1 . There was no case of hepatic cancer among the 29 cases. Causes of death in these 29 cases were as follow: bonchopneumonia, 8; subdural hematoma, 3; purulent peritonitis, 3 ; heart failure, 3 ; hepatic failure, 2; cerebral hemorrhages, 2; and others, 8. Among the other causes of death, one case of esophageal carcinoma and one of chronic pancreatitis associated with lithiasis were included. Okudaira (1966) also described 15 autopsied cases of chronic alcoholics showing fatty liver ( 6 cases) and fatty cirrhosis of the liver (9 cases). There was no complication of hepatocellular carcinoma in these cases.

According to the investigation of Japanese autopsy cases from 1958 to 1973 by Miyaji (1977), 23.3\% of the hepatic cirrhosis cases were complicated by hepatocellular carcinoma. For alcoholic cirrhosis (fatty nutritional cirrhosis), rates of complicated malignancy were reported to be comparatively low (Sagebiel et al., 1963: 0\%, Hoensch, 1972: 1\% and Purtilo \& Gottlieb, 1973: 3.2\%).

Recently some reports clarified that hepatocellular carcinoma accompanied by cirrhosis frequently contained positive hepatitis-associated antigen in the liver cells as well as in the serum (Nakashima \& Sakamoto, 1977, and Okuda \& Kubo, 1977). In this connection, Purtilo \& Gottlieb(1973) suggested that chronic alcoholism and hepatitis-associated antigen probably could act synergistically to produce postnecrotic cirrhosis, the frequency of which of $24.2 \%$ was associated with hepatoma.

One of the other prominent effects of ethanol ingestion is the influence on the pancreas. Horie et al. (1977) made a comparative histopathological study of autopsied pancreata free from decomposition between a group of elderly cases (159 cases, average 75 years-old) and a group of alcoholic cases (25 cases, average 56 year-old). Mucus cell hyperplasia, squamous metaplasia of the ductal epithelium and atypical hyperplasia(Fig.4) were described more frequently in the pancreata of the aged group than of the alcoholic group. On the contrary, frequent occurrences of duct dilatation and inflammatory cell infiltration associated with inspissated secretion (Fig.3) as well as of venous dilatation related to portal hypertension due to hepatic cirrhosis were reported in the alcoholic group in comparison with the aged group.

These facts mean that paraplasm such as mucus cell hyperplasia, squamous metaplasia, and atypical hyperplasia of the epithelium was more prevalent in the aged group and not so in the alcoholic group. Moreover, according to epidemiological evaluation of pancreatic cancer by Wynder (1975), alcoholic intake had no association with carcinoma of the pancreas, in spite of a positive correlation between this cancer and smoking. With reference to this problem, more comprehensive study is needed to clarify the causal relationship between drinking of alcoholic beverages and carinogenesis of the liver as well as of the pancreas. 
All of the cited experimental studies in which the author participated were designed by Prof. Masanori Kuratsune, Department of Public Health, Faculty of Medicine, Kyushu University. The author would like to express his sincere appreciation to Prof. Kuratsune for his kind direction in this regard. In addition the author owes thanks to Dr. Yasuo Nishihara, President of Kurate Kyoritsu Hospital, for the investigation of the autopsied alcoholics.

\section{References}

Creutzfeldt, W. \& Schmidt, H. (1970): Aetiology and pathogenesis of pancreatitis (current concepts). Scand. J. Gastroent., Suppl. 6: 47-62.

Doll, R. \& Hill, A. B. (1964): Mortality in relation to smoking. Ten years' observation on British doctors. Brit. Med. J., 1: 1460-1467.

Hoensch, H. (1972): The aetiology and pathogenesis of the malignant tumours of the liver. Digestion, 5: $58-63$.

Horie, A., Kohchi, S. \& Kuratsune, M. (1965): Carcinogenesis in the esophagus. II. Experimental production of esophageal cancer by administration of ethanolic solution of carcinogens. Gann, 56: $429-441$.

Horie, A., Kotoo, Y. \& Nishihara, Y. (1977): Histopathological findings of the pancreas in the aged and alcoholics. Jap. J. Geront., 14: 468-474. (in Japanese with English abstract)

Horie, A., Okumura, Y. \& Nishihara, Y. (1978): Hepatic lesions of 29 autopsied alcoholics in Chikuho district. Jap. Clin. Med., 50: 2038-2044. (in Japanese)

Kuratsune, M., Kohchi, S. \& Horie, A. (1965): Carcinogenesis in the esophagus. I. Penetration of benzo[ $[a]$ pyrene and other hydrocarbons into the esophageal mucosa. Gann, 56: 177-187.

Kuratsune, M., Kohchi, S., Horie, A. et al. (1971): Test of alcoholic beverages and ethanol solutions for carcinogenecity and tumor-promoting activity. Gann, 62: 395-405.

Miyaji, T. (1977): A close association of hepatocellular carcinoma with cirrhotic changes among 275, 857 pathological autopsy cases in Japan during 16 years from 1958 to 1973 . Kurume Med. J. , 24(Suppl. ): S63-S79.

Moriwaki, H., Noda, H. \& Horie, A. (1973): An autopsy case of diffuse disseminated pancreatolithiasis. Iryo, 27: 80-84. (in Japanese with English abstract)

Nakashima, T. \& Sakamoto, K. (1977): A study of hepatocellular carcinoma among Japanese from the point of view of morpho-developmental pathology-gross anatomical types classified in its relation to capsule formation. Kurume Med. J., 24(Suppl.): S43-S62.

Okuda, K. \& Kubo, Y. (1977): Clinical diagnosis of hepatocellular carcinoma. Kurume Med. J., 24 (Suppl. ) : S81-S112.

Okudaira, M. (1966): Symposium I. Alcohol and the liver. 1) Alcoholism and the liver, with regard to the morphological changes of the liver. Acta Hepatol. Jap., 7 (Suppl. 1): 53-58.

Purtilo, D. T. \& Gottlieb, L. S. (1973): Cirrhosis and hepatoma occurring at Boston City Hospital (1917-1968). Cancer, 32: 458-462.

Sagebiel, R.W., McFarland, R.B., \& Taft, E.B. (1963): Primary carcinoma of the liver in relation to cirrhosis. Amer. J. Clin. Path., 40: 516-520.

Sarles, H. (1974): Chronic calcifying pancreatitis - chronic alcoholic pancreatitis. Gastroenterology, 66: 604-616.

Segi, M. \& Kurihara, M. (1969): Cancer mortality for selected sites in 24 countries. No. 5, Department of Public Health, Tohoku University, School of Medicine.

Sereny, G. \& Devenyi, P. (1972): Portal fibrosis in alcoholic liver disease. Amer. J. Gastroent., 57 : $429-434$.

Wynder, E. L. (1975): An epidemiological evaluation of the causes of cancer of the pancreas. Cancer Res. , 35: 2228-2233. 
酒と食道・肝・膵の癌

堀 江 明 夫

産業医科大学第一病理学教室

要旨：これまで飲酒と食道癌との関係を実験的に研究し、また、大酒冢剖検例の肝と膵の病変 を調査した報告の紹介である。

食道では酒類に含まれるエタノールが発㽞性芳香族炭化水素の溶媒となって粘膜内滲透 を助長し、発癌に関与すると考光られる。

他方、エタノールだけの投与では発癌は夕られなかったが、日本酒およびその蒸溜残渣 にはクロトン油に匹敵する程度の発癌促進作用が認められた。

また、大酒家29剖検例の調査では、1例の食道癌の他に肝硬変症や膵炎はみられたが、 それら蔵器の癌は認められなかった。

産業医大誌， 1(1)：69-75（1979） 